\title{
THE MAJOR BIOLOGICAL APPROACHES IN THE INTEGRATED PEST MANAGEMENT OF ONION THRIPS, THRIPS TABACI (THYSANOPTERA: THRIPIDAE)
}

\author{
A review \\ Wondimagegn Atilaw WOLDEMELAK \\ Szent István University, Department of Entomology, Villányi str. 29-43, Budapest, Hungary
}

Received: December 2019; Accepted: February 2020

\begin{abstract}
Thrips tabaci Lindeman is a cosmopolitan and polyphagous insect pest. It is known worldwide and recorded on more than 300 plant species. T. tabaci is a key pest of onion and several other crops, and its control is vital to the production and profitability of crops. If onion thrips population is not controlled, damage can reduce yield volume and quality. In addition to direct damage to the host plants, T. tabaci has been characterized as an asymptomatic vector of three devastating tospovirus species, such as Tomato spotted wilt virus, Iris yellow spot virus, and Tomato yellow ring virus. For this reason, several synthetic insecticides were used for control. However, these insecticides bring unwanted effects, like pesticide resistance, elimination of nontarget species, environmental pollution, and threats to human health. To solve the negative consequences of insecticides, biopesticides, such as plant secondary metabolites, entomopathogenic viruses, bacteria, fungi, and nematodes, have been recognized as effective alternatives. The use of plantbased insecticides and entomopathogenic control methods gained more attention in integrated pest management. Their strong side is lack of residues, saving beneficial insects and minimizing air and water pollution. Plant-derived compounds and entomopathogenic biological control agents offered a variety of biological modes of actions against onion thrips, such as repellency, feeding deterrence, anti-oviposition, fecundity deterrence, metamorphosis inhibition, and parasiting the host's body.
\end{abstract}

Key words: biological control, ecosystem, mode of action, onion thrips, polyphagous secondary metabolites

\section{INTRODUCTION}

Of the 6000 currently identified thrips species (Thysanoptera), only about $1 \%$ is recorded as economically important pests (Morse \& Hoddle 2006). This figure has implied that the thrips are a major problem in agriculture. Thrips tabaci Lindeman is among one of the major polyphagous species since it has been recorded to occur on more than 300 plant species. If thrips are not controlled, damage can reduce yield and quality and even are more problematic due to transmission of different devastating viruses.

To this day, synthetic pesticides are extensively used against onion thrips. However, the cryp- tic nature, high reproductive capacity, multi-generations per year, hidden lifestyle (pupation in the soil), and polyphagous nature make them hard to control by this way. Repeated application of chemical insecticides in the field and greenhouse often favors unwanted effects such as pesticide resistance, elimination of nontarget species, pest resurgence, and secondary pest outbreaks (Foster et al. 2010).

To solve all the above drawbacks of insecticides, the use of environmentally friendly integrated pest management (IPM) is the most recommended. In this context, aromatic plants and entomopathogenic organisms offer better alternatives to synthetic pesticides and are effective against onion 
thrips. The aromatic plants contain various bioactive insecticidal compounds, and the entomopathogenic biological control agents are effective to cause lethal effects on the targeted pests without affecting the environment. Numerous plant species, including aromatic plants and their essential oils (Harrewijn et al. 1994), entomopathogenic biological agents, fungi, viruses, bacteria, and nematodes are appreciated in regard to IPM. Currently, the use of plantbased insecticides and entomopathogenic agents has gained more attention in IPM. The positive effects of using biological protection are: lack of residues, which is a matter of substantial concern for consumers, specific target, usually slow building of resistance against protective effect, lack of negative effects on beneficial insects, and no pollution of air and water, generally, saving the environment. Aromatic plants have developed manifold mode of actions against pests, including metamorphosis interference, feeding and ovipositional deterrence, and other kinds of repellency (Regnault-Roger 1997). Entomopathogenic biological agents have developed different modes of actions, for example paralyzing and predating their hosts. Thus, in the context of onion thrips management, plant-based pesticides and entomopathogenic biological agents are effective in pest controlling with environmental safety and human health care.

This review has aimed to provide information from research literature about the most effective biopesticides, their mode of actions, and approaches to their potential method of applications against onion thrips.

\section{Damage caused by onion thrips}

Both adults and larvae of onion thrips cause damage to their hosts by piercing the surface tissues and sucking the contents of plant cells. This damage caused the photosynthetic capacity of plants to decrease (Lewis 1973). In addition to direct damage to the crops, T. tabaci is a vector of three devastating tospovirus species, such as Tomato spotted wilt virus (TSWV), Iris yellow spot virus (IYSV) and Tomato yellow ring virus (TYRV) (Berniak 2016; Cortês et al. 1998; Macharia et al. 2015; Rotenberg et al. 2015; Wijkamp et al. 1995). The direct and indirect damages of onion thrips led to reduce the total yield from 4 to $27 \%$ and the bulb size from 28 to $73 \%$ (Fournier et al. 1995; Lewis 1973).

\section{Monitoring and treatment decisions with regard to onion thrips and sampling}

Early identification of pest species is an important component to designing IPM strategies. Onion thrips emerge from overwintering sites and colonize weeds and any other volunteer plants. They highly invade the onion field margins at the early- and midspring seasons and then disseminate to the inside parts of onion farm, so, at the beginning of the spring, samplings should be taken from boarder plants. As onion thrips prefer the younger stages of the plant, the primary samplings should be taken from the young onion plants in the lowest center part of the leaf sheath (Shelton et al. 1987).

The infestation of onion fields with thrips should be evaluated using sticky boards, glue-based traps made of high-quality polypropylene material. However, the efficiency level is dependent on their color, which can differ for different pests. For example, for whiteflies and aphids yellow sticky board is effective, whereas for thrips species blue is reliably effective (Jasrotia et al. 2016). The number of onion thrips from sticky boards and plant samples should be counted in the laboratory. Management decisions are made based on the plant colonization threshold.

\section{Action threshold}

It is one of the most important decision-making elements in IPM. The reliable treatment threshold level for T. tabaci hypothesized by season (dry or rainy) and the resistance level of crop cultivars should be taken into account. The adopted colonization thresholds are different. For example, the following threshold levels were suggested: in California - 30 thrips per plant (Edelson et al. 1989), in New York state -3 per leaf (Nault \& Shelton 2012), in Ethiopia - 5-10 per plant (Shiberu \& Mahammed 2014), and in Honduras - 0.5-1.6 per leaf in the dry season (Rueda et al. 2007).

\section{Ways to control onion thrips \\ Aromatic plants}

Aromatic plants are currently widely used in different fields and for different purposes particularly in medicine, pharmacy, cosmetology, and agriculture due to several essential oils produced in their roots, 
leaves, flowers, seeds, and stems. The most dominant active compounds extracted from aromatic plants are alkaloids, nonproteic amino acids, steroids, phenols, flavonoids, glycosides, glucosinolates, quinones, tannins, terpenoids, salanine, meliantrol, azadirachtin, piretrolone, cinerolone, and jasmolone (Abe et al 2008; Howe \& Jander 2008; VallverdúQueralt et al. 2014).

There have been trials to establish aromatic insecticides from various plant species to control onion thrips at field and greenhouse conditions and the following have been recommended: Artemisia arborescens, Azadirachta indica L., Chrysanthemum cinerariifolium, Datura stramonium, Dodonaea angustifolia L., Dianthus caryophyllus, Melaleuca alternifolia, Nicotiana glauca, Origanum majorana, Ocimum gratissimum, Rosmarinus officinalis, and Tagetes minuta (Fitiwy et al. 2015; Omosa et al. 2016; Prabhu et al. 2011; Shiberu \& Negeri 2014; van Tol et al. 2007).

Aromatic plants are applied as spraying in field and greenhouse conditions and used according to procedures similar to those applied to chemical insecticides (Stepanycheva et al. 2019). The extracted essential oils diluted in water or formulated products are sprayed before planting or later foliarly. A recent study reported that pulverized neem plant has systemic action when sprayed onto the soil and thus roots absorb it and translocate within the body. Sometimes aromatic insecticides can be effective in the form of fumigation in greenhouse (Koschier 2008).

However, the effectiveness of some aromatic plant products may be insufficient at high density of onion thrips. The reason for the decreasing of their controlling efficiency may be due to short residual property of the prepared plant parts and their rapid oil volatility that make them less toxic to the targeted pests. For this matter, with a practical point of view, aromatic plants may be more effective when they are mixed with other control methods. It is recommended that weekly repeated applications at least three times until harvest should be necessary to decrease the density of onion thrips below the economic injury level. Aromatic plants are much more effective in a condition where the population of onion thrips is lower or moderate (Nault \& Shelton 2012). In Ethiopia, Nicotiana spp., Phytolacca dodecandra, Securidaca longipedunculata, and $\mathrm{Ni}$ cotiana tabacum were effective against onion thrips under field condition (Shiberu et al. 2013).

Plant-based bioactive compounds offer a variety of biological mode of action against onion thrips - acting as attractants, repellents, antifeedants, antioviposition agents, poisoners, fertility reducers, perpetrators of egg sterility, and metamorphosis inhibitors (Koschier \& Sedy 2002, 2003; Saniewski et al. 2014; Nerio et al. 2010).

\section{Attractant activity}

Onion thrips are small insects and live in the curled leaves, which leads to omitting them easily during monitoring. This problem can be solved by placing mentioned above colored sticky boards as traps (Vernon \& Gillespie 1990). Trap effectiveness could be increased by combining an attractive color cue with an attractive odor cue (Teulon et al. 2007). An attractive odor derived from aromatic plants is a complex mixture of different secondary metabolites such as monoterpenes, sesquiterpenes, and phenylpropanoid compounds. Combining two or more attractive secondary metabolites to increase their effectiveness could seem a common practice toward trap efficiency improvement. However, the mixing of p-anisaldehyde and methyl isonicotinate had less efficiency for onion thrips compared to applying them separately (Teulon et al. 2007). This implies that onion thrips would have only one odor receptor, therefore blended compounds could mask each other (Koschier 2008; Nottingham et al. 1991).

\section{Repellent activity}

Plants produce odors that often are repellents to numerous species of insects. Therefore, colonization is preceded with testing various plant cues such as color, shape, and size of the plants (Lewis 1973). Repellents are products of secondary metabolites, used as olfactory messengers to interfere, and discourage insects from landing or movement onto plant surface. In New Zealand, onion thrips was repelled by $R$. officinalis essential oil and deterred by $D$. angustifolia, $O$. gratissimum, and $O$. majorana essential oils, and the controlling efficiency against onion thrips was about 71-87\% (van Tol et al. 2007).

\section{Oviposition deterrents}

The interaction of the plant and pathogen is not limited to feeding but also with a interfering with eggs 
deposition. Plant nutritional quality, particularly nitrogen content, architecture, morphology, anatomy, and secondary compounds have been reported as detrimental factors for ovipositional choice of female thrips (Koschier \& Sedy 2003; Singh \& Saratchandra 2005). A field study with $A$. indica extracts showed that the action against onion thrips was correlated with nutritional deterrence and discouraging egg lay, as well as with toxicity and infertility. The physiological toxicity of azadirachtin is based on growth retardation, which reduces the female fecundity, and thus reduces the density of thrips on onion (Shiberu \& Negeri 2014).

\section{Metamorphosis deterrents}

Metamorphosis is a gradual change in every developmental stage of insects. This process leads to change insects' form, structure, and size and is after all used to determine the survival rates of insects. Juvenile hormones synthesized by endocrine glands involve in every developmental stage of insects. They determine whether the next stage is larval-larval, larval-prepupal, prepupal-pupal, or pupal-adult. The secondary metabolites produced by plants mimic prothoracicotropic hormone (PTTH) and block ecdysone that refuses the next metamorphosis stage and, finally, leads to death (Schmutterer 1990). Therefore, neem extract was used to prevent insect hormone production, thereby interfering with their maturation on a scale large enough to suppress their reproduction (Dang et al. 2012).

\section{Entomopathogenic fungi}

Some fungi species have the ability to kill insects by their colonization. Beauveria bassiana, Metarhizium anisopliae, Lecanicillium (Verticillium) lecanii/muscarium, Entomophthora parvispora, Entomophthora thripidum, Paecilomyces lilacinus, and Neozygites parvispora have been tested against onion thrips (Abe \& Ikegami 2005; Annamalai et al. 2013; Carl 1975; Ezzati-Tabrizi et al. 2009; MacLeod et al. 1976; Maniania et al. 2003; Samson et al. 1979; Wu et al. 2016). According to Thungrabeab et al. (2006) about 36 isolated entomopathogenic fungi species successfully lowered the onion thrips population; however the pathogenic efficiency varied among the species. In another report, $B$. bassiana significantly lowered the population of larval and adult stages of onion thrips under greenhouse conditions
(Wu et al. 2014). A study in western Kenya documented that the entomogenous fungus $M$. anisopliae has the potential to control thrips in onion (Maniania et al. 2003). In Ethiopia, B. bassiana significantly decreased onion thrips density at field condition.

The mode of actions of these entomopathogenic fungi is associated with their contact with the host insects. These fungal species often need wet conditions to allow the filamentous growth and production of conidia. The infection processes involve: 1. attachment of the spore to the host's cuticle; 2. germination of hyphae on cuticle that produce enzymes, such as proteases, chitinases, quitobiases, upases, and lipoxygenases, which penetrate the host's cuticles and epidermis, degrading the insect's cuticle that facilitates the process of penetration; 3. once hyphae entered to inside of the host's body they disseminate through the hemocele and invade different tissues, fatty bodies, Malpighian tubules, mitochondria, and hemocytes, leading to death of the insect within 3-14 days after infection. Once the insect dies and many of the nutrients are exhausted, fungi start micellar growth and invade all the organs of the host. Finally, hyphae penetrate the cuticle from the interior of the insect and emerge at the surface, where they initiate spore formation under appropriate environmental conditions (Senthil-Nathan 2015).

\section{Entomopathogenic nematodes}

Nematodes are present in the soil and cover crops, and affect insects upon contacts (Chałańska \& Łabanowski 2014). Steinernema and Heterorhabditis are the two most studied nematode genera that were suggested as biocontrol agents against insects. The most effective nematode species against onion thrips are Heterorhabditis spp., Steinernema feltiae, Steinernema carpocapsae, Heterorhabditis bacteriophora, and Heterorhabditis indica (Azazy et al. 2018; Bedding \& Molyneux 1982; Kashkouli et al. 2014). Usually entomopathogenic nematodes are effective when they are applied to moist soil and in the evening or early morning. Post-irrigation application increases the effectiveness of nematode establishment and washes the nematodes from the leaves into the soil, which is their natural reservoir (Simões \& Rosa 1996). In the Netherlands, Great Britain, and Germany the use of entomopathogenic nematodes in the field is approved either solely or 
in a mixture utilizing common spray equipment (Jung 2004). In Egypt, foliar spraying of H. bacteriophora and $H$. indica with adequate concentrations was successful in lowering the onion thrips populations at field conditions (Azazy et al. 2018). These entomopathogenic nematodes were more effective on nymphal stages than adults. $S$. carpocapsae, S.feltiae, and $H$. bacteriophora were tested against onion thrips in the laboratory and were more effective on prepupa and pupa stages (Kashkouli et al. 2014).

The modes of actions of the entomopathogenic nematodes are: 1 . infective juvenile nematodes migrate and search new hosts and colonize them entering the hosts' body through mouth, anus, and spiracle; 2. these nematodes release Xenorhabdus bacteria to kill the host; 3. the parasites Heterorhabditidae and Steinernematidae transform into adults in the dead hosts' body; 4. adult females and males of Heterorhabditidae and Steinernematidae reproduce in the dead hosts; 5 . eggs of the parasites passes different developmental stages and the third juvenile stage again begin to search the new hosts (SenthilNathan 2015).

\section{Predator mites}

The effective predators of the onion thrips are Orius albidipennis, Neoseiulus cucumeris, Amblyseius cucumeris, Amblyseius barkeri, Orius strigicollis, Amblyseius swirskii, Deraeocoris pallens, Franklinothrips vespiformis, Chrysopa vulgaris, Chrysopa carnea, and Medetera ambigua (Brødsgaard \& Stengård Hansen 1992; Gillespie 1989; Lewis 1973; Madadi et al. 2007; Wu et al. 2014). In Denmark, the control efficiency of A. cucumeris and A. barkeri was compared under greenhouse condition, where A. cucumeris was more effective than A. barkeri (Brødsgaard \& Stengård Hansen 1992). According to $\mathrm{Wu}$ et al. (2014), in greenhouse condition, 250 Stratiolaelaos scimitus and Neoseiulus barkeri per $\mathrm{m}^{2}$ each were effective against onion thrips. The control of $N$. cucumeris against onion thrips was more efficient on sweet pepper than on cucumber and eggplant. This difference may be related to the plant surface structure, and the presence of glandular trichomes, leaf hair, thorns, odors, and spines that may affect the search pattern and the behavioral response of predators (Madadi et al. 2007.

\section{Parasitoids}

The most important parasites of thrips are endoparasitoids infecting the body of their host and ultimately killing the hosts. Parasitoid Ceranisus menes was significantly more efficient to suppress onion thrips than predators. The control efficiency of parasitoids against onion thrips depends on the host plant species; e.g. - in India, control performance of parasitoids on onion was significantly higher than that on garlic (Jayanthi Mala \& Nighot 2013). The speculated reason behind is the odor of garlic that may repel parasitoids.

\section{Conclusion and future recommendation}

T. tabaci is a key pest on a wide range of crop and weed species. It is also an asymptomatic vector of three devastating tospoviruses - TSWV, IYSV, and TYRV. T. tabaci developed a resistance to different types of chemical insecticides and it is a challenge to develop effective management in relation to environmental aspects.

Aromatic plant-based insecticides and biological control agents are alternative options against onion thrips in regard to IPM. Nowadays, the effectiveness of several plant products and biological control agents has been screened in a small-scale farm and at a laboratory condition. However, the development and application of plants and their bioactive constituents are limited at a commercial level. Thus, it is time to enlarge the production and availability of these plant pesticides at a commercial level for future research. Actually, biological control agents have been investigated as a potent alternative to control onion thrips in laboratories and greenhouses but rarely at field conditions. Therefore, actual research goal is to propose efficient technologies usable at field levels.

\section{REFERENCES}

Abe M., Ikegami T. 2005. Susceptibility of five species of thrips to different strains of the entomopathogenic fungus, Beauveria bassiana. Applied Entomology and Zoology 40: 667-674. DOI: 10.1303/aez.2005.667.

Abe H., Ohnishi J., Narusaka M., Seo S., Narusaka Y., Tsuda S., Kobayashi M. 2008. Function of jasmonate in response and tolerance of Arabidopsis to thrip feeding. Plant and Cell Physiology 49: 6880. DOI: $10.1093 / \mathrm{pcp} / \mathrm{pcm} 168$. 
Annamalai M., Kaushik H.D., Selvaraj K. 2013. Pathogenicity of Beauveria bassiana (Balsamo) Vuillemin and Lecanicillium lecanii Zimmerman against onion thrips, Thrips tabaci Lindeman. Biopesticides International 9(2): 148-156.

Azazy A.M., Abdelall M.F.M., El-Sappagh I.A., Khalil A.E.H. 2018. Biological control of the onion thrips, Thrips tabaci Lindeman (Thysanoptera: Thripidae), in open fields using Egyptian entomopathogenic nematode isolates. Egyptian Journal of Biological Pest Control 28(1); 27, 6 p. DOI: 10.1186/s41938-017-0025-9.

Bedding R.A., Molyneux A.S. 1982. Penetration of insect cuticle by infective juveniles of Heterorhabditis spp. (Heterorhabditidae: Nematoda). Nematologica 28: 354-359. DOI: 10.1163/187529282x00402.

Berniak H. 2016. Characterization of a new tomato spotted wilt virus isolates found in Hippeastrum hybridum (Hort.) plants in Poland. Journal of Horticultural Research 24(1): 5-12. DOI: 10.1515/johr2016-0001.

Brødsgaard H.F., Stengård Hansen L. 1992. Effect of Amblyseius cucumeris and Amblyseius barkeri as biological control agents of Thrips tabaci on glasshouse cucumbers. Biocontrol Science and Technology 2: 215-223. DOI: 10.1080/09583159209355235.

Carl K.P. 1975. An Entomophthora sp. (Entomophthorales: Entomophthoraceae) pathogenic to Thrips spp. (Thysan.: Thripidae) and its potential as a biological control agent in glasshouses. Entomophaga 20: 381-388. DOI: 10.1007/bf02371592.

Chałańska A., Łabanowski G. 2014. The effect of edaphic factors on the similarity of parasitic nematodes in the soil sampled in nurseries of ornamental trees and shrubs. Journal of Horticultural Research 22(1): 21-28. DOI: 10.2478/johr-2014-0002.

Cortês I., Livieratos I.C., Derks A., Peters D., Kormelink R. 1998. Molecular and serological characterization of iris yellow spot virus, a new and distinct tospovirus species. Phytopathology 88: 12761282. DOI: $10.1094 /$ phyto.1998.88.12.1276.

Dang Q.L., Lim C.H., Kim J.-C. 2012. Current status of botanical pesticides for crop protection. Research in Plant Disease 18: 175-185. DOI: 10.5423/rpd.2012.18.3.175.

Edelson J.V., Cartwright B., Royer T.A. 1989. Economics of controlling onion thrips (Thysanoptera: Thripidae) on onions with insecticides in south Texas. Journal of Economic Entomology 82: 561564. DOI: 10.1093/jee/82.2.561.
Ezzati-Tabrizi R., Talaei-Hassanloui R., Pourian H.-R. 2009. Effect of formulating of Beauveria bassiana conidia on their viability and pathogenicity to the onion thrips, Thrips tabaci Lind. (Thysanoptera: Thripidae). Journal of Plant Protection Research 49(1): 97-104. DOI: 10.2478/v10045-009-0013-5.

Fitiwy I., Gebretsadkan A., Ayimut K.-M. 2015. Evaluation of botanicals for onion thrips, Thrips tabaci Lindeman, (Thysanoptera: Thripidae) control at Gum Selassa, South Tigray, Ethiopia. Momona Ethiopian Journal of Science 7: 32-45. DOI: 10.4314/mejs.v7i1.117234.

Foster S.P., Gorman K., Denholm I. 2010. English field samples of Thrips tabaci show strong and ubiquitous resistance to deltamethrin. Pest Management Science 66: 861-864. DOI: 10.1002/ps.1953.

Fournier F., Boivin G., Stewart R.K. 1995. Effect of Thrips tabaci (Thysanoptera: Thripidae) on yellow onion yields and economic thresholds for its management. Journal of Economic Entomology 88: 1401-1407. DOI: 10.1093/jee/88.5.1401.

Gillespie D.R. 1989. Biological control of thrips (Thysanoptera: Thripidae) on greenhouse cucumber by Amblyseius cucumeris. Entomophaga 34: 185-192. DOI: $10.1007 /$ bf02372667.

Grewal P., Georgis R. 1999. Entomopathogenic nematodes. In: Hall F.R., Menn J.J. (Eds.), Biopesticides: Use and Delivery. Humana Press, USA, pp. 271-299. DOI: 10.1385/0-89603-515-8:271.

Harrewijn P., Minks A.K., Mollema C. 1994. Evolution of plant volatile production in insect-plant relationships. Chemoecology 5: 55-73. DOI: $10.1007 / \mathrm{bf} 01259434$.

Howe G.A., Jander G. 2008. Plant immunity to insect herbivores. Annual Review of Plant Biology 59: 41-66. DOI: 10.1146/annurev.arplant.59.032607.092825.

Jayanthi Mala B.R., Nighot P. 2013. Natural enemy complex of Thrips tabaci Lindeman in onion and garlic. Pest Management in Horticultural Ecosystems 19: 121-122.

Jasrotia P., Nataraja M.V., Harish G., Dutta R., Savaliya S.D. 2016. Effect of trap design and weather factors on relative efficiency of yellow sticky traps for sampling aphids in groundnut. Legume Research 39: 834-839. DOI: 10.18805/lr.v0iof.9290.

Jung K. 2004. Combined use of insect pathogenic fungi and nematodes against the onion thrips, Thrips tabaci, in the field. IOBC/WPRS Bulletin 27: 141-143.

Kashkouli M., Khajehali J., Poorjavad N. 2014. Impact of entomopathogenic nematodes on Thrips tabaci Lindeman (Thysanoptera: Thripidae) life stages in 
the laboratory and under semi-field conditions. Journal of Biopesticides 7: 77-84.

Koschier E.H. 2008. Essential oil compounds for thrips control - A review. Natural Product Communications 3: 1171:1182. DOI: 10.1177/1934578x0800300726.

Koschier E.H., Sedy K.A. 2002. Effects of plant volatiles on the feeding and oviposition of Thrips tabaci. Thrips and Tospoviruses. Proceedings of the $7^{\text {th }}$ International Symposium on Thysanoptera. Italy, 27 July, 2001, pp. 185-187.

Koschier E.H., Sedy K.A. 2003. Labiate essential oils affecting host selection and acceptance of Thrips tabaci Lindeman. Crop Protection 22: 929-934. DOI: 10.1016/s0261-2194(03)00092-9.

Lewis T. 1973. Thrips: their biology, ecology and economic importance. Academic Press, USA, 349 p.

Macharia I., Backhouse D., Skilton R., Ateka E., Wu S.B., Njahira M. et al. 2015. Diversity of thrips species and vectors of tomato spotted wilt virus in tomato production systems in Kenya. Journal of Economic Entomology 108: 20-28. DOI: 10.1093/jee/tou010.

MacLeod D.M., Tyrrell D., Karl K.P. 1976. Entomophthora parvispora sp. nov., a pathogen of Thrips tabaci. Entomophaga 21: 307-312.

Madadi H., Enkegaard A., Brodsgaard H.F., KharraziPakdel A., Mohaghegh J., Ashouri A. 2007. Host plant effects on the functional response of Neoseiulus cucumeris to onion thrips larvae. Journal of Applied Entomology 131: 728-733. DOI: 10.1111/j.1439-0418.2007.01206.x.

Maniania N.K., Sithanantham S., Ekesi S., AmpongNyarko K., Baumgärtner J., Löhr B., Matoka C.M. 2003. A field trial of the entomogenous fungus $M e$ tarhizium anisopliae for control of onion thrips, Thrips tabaci. Crop Protection 22: 553-559. DOI: 10.1016/s0261-2194(02)00221-1.

Morse J.G., Hoddle M.S. 2006. Invasion biology of thrips. Annual Review of Entomology 51: 67-89. DOI: 10.1146/annurev.ento.51.110104.151044.

Nault B., Shelton A. 2012. Guidelines for managing onion thrips on onion. Cornell University. Veg Edge 8(5): 14-17.

Nerio L.S., Olivero-Verbel J., Stashenko E. 2010. Repellent activity of essential oils: A review. Bioresource Technology 101: 372-378. DOI: 10.1016/j.biortech.2009.07.048.

Nottingham S.F., Hardie J., Dawson G.W., Hick A.J., Pickett J.A., Wadhams L.J., Woodcock C.M. 1991. Behavioral and electrophysiological responses of aphids to host and nonhost plant volatiles. Journal of Chemical Ecology 17: 1231-1242. DOI: 10.1007/bf01402946.

Omosa L.K., Akala H., Kenanda E.O., Ndunda B. 2016. Variability of surface exudates of Dodonaea angustifolia L.f, antioxidant and antiplasmodial activities of the compounds. Journal of Natural Sciences Research 6: 78-85.

Prabhu K., Murugan K., Nareshkumar A., Ramasubramanian N., Bragadeeswaran S. 2011. Larvicidal and repellent potential of Moringa oleifera against malarial vector, Anopheles stephensi Liston (Insecta: Diptera: Culicidae). Asian Pacific Journal of Tropical Biomedicine 1: 124-129. DOI: 10.1016/s2221-1691(11)60009-9.

Regnault-Roger C. 1997. The potential of botanical essential oils for insect pest control. Integrated Pest Management Reviews 2: 25-34. DOI: 10.1023/a:1018472227889.

Rotenberg D., Jacobson A.L., Schneweis D.J., Whitfield A.E. 2015. Thrips transmission of tospoviruses. Current Opinion in Virology 15: 80-89. DOI: 10.1016/j.coviro.2015.08.003.

Rueda A., Badenes-Perez F.R., Shelton A.M. 2007. Developing economic thresholds for onion thrips in Honduras. Crop Protection 26: 1099-1107. DOI: 10.1016/j.cropro.2006.10.002.

Samson R.A., Ramakers P.M.J., Oswald T. 1979. Entomophthora thripidum, a new fungal pathogen of Thrips tabaci. Canadian Journal of Botany 57: 1317-1323. DOI: 10.1139/b79-161.

Saniewski M., Horbowicz M., Kanlayanarat S. 2014. The biological activities of troponoids and their use in agriculture. Journal of Horticultural Research 22(1): 5-19. DOI: 10.2478/johr-2014-0001.

Schmutterer H. 1990. Properties and potential of natural pesticides from the neem tree, Azadirachta indica. Annual Review of Entomology 35: 271-297. DOI: 10.1146/annurev.en.35.010190.001415.

Senthil-Nathan S. 2015. A review of biopesticides and their mode of action against insect pests. In: Thangavel P., Sridevi G. (Eds.), Environmental Sustainability. Springer, India, pp. 49-63. DOI: 10.1007/978-81-322-2056-5_3.

Shelton A.M., Nyrop J.P., North R.C., Petzoldt C., Foster R. 1987. Development and use of a dynamic sequential sampling program for onion thrips, Thrips tabaci (Thysanoptera: Thripidae), on onions. Journal of Economic Entomology 80: 1051-1056. DOI: 10.1093/jee/80.5.1051.

Shiberu T., Mahammed A. 2014. The importance and management option of onion thrips, Thrips tabaci 
(L.) (Thysanoptera: Thripidae) in Ethiopia : A review. Journal of Horticulture 1; 107; 6 p. DOI: 10.4172/2376-0354.1000107.

Shiberu T., Negeri M. 2014. Evaluation of insecticides and botanicals against onion thrips, Thrips tabaci (L.) (Thysanoptera: Thripidae). Entomology and Applied Science Letters 1: 26-30.

Shiberu T., Negeri M., Selvaraj T. 2013. Evaluation of some botanicals and entomopathogenic fungi for the control of onion thrips (Thrips tabaci L.) in West Showa, Ethiopia. Journal of Plant Pathology and Microbiology 4; 161; 7 p. DOI: 10.4172/21577471.1000161.

Simões N., Rosa J.S. 1996. Pathogenicity and host specificity of entomopathogenic nematodes. Biocontrol Science and Technology 6: 403-412. DOI: 10.1080/09583159631370.

Singh R.N., Saratchandra B. 2005. The development of botanical products with special reference to seriecosystem. Caspian Journal of Environmental Sciences 3: 1-8.

Stepanycheva E., Petrova M., Chermenskaya T., Pavela R. 2019. Fumigant effect of essential oils on mortality and fertility of thrips Frankliniella occidentalis Perg. Environmental Science and Pollution Research 26: 30885-30892. DOI: 10.1007/s11356019-06239-y.

Teulon D.A.J., Nielsen M.-C., James D.E., Winkler S., McLachlan A.R.G., Perry N.B. 2007. Combination of two odour chemical lures does not increase thrips capture in field bioassays. New Zealand Plant Protection 60: 61-66. DOI: 10.30843/nzpp.2007.60.4610.

Thungrabeab M., Blaeser P., Sengonca C. 2006. Effect of temperature and host plant on the efficacy of different entomopathogenic fungi from Thailand against Frankliniella occidentalis (Pergande) and Thrips tabaci Lindeman (Thysanoptera: Thripidae) in the laboratory. Journal of Plant Diseases and Protection 113: 181-187. DOI: 10.1007/bf03356177.

van Tol R.W.H.M., James D.E., de Kogel W.J., Teulon D.A.J. 2007. Plant odours with potential for a push-pull strategy to control the onion thrips, Thrips tabaci. Entomologia Experimentalis et Applicata 122: 69-76. DOI: 10.1111/j.15707458.2006.00489.x.

Vallverdú-Queralt A., Regueiro J., Martínez-Huélamo M., Rinaldi Alvarenga J.F., Leal L.N., LamuelaRaventos R.M. 2014. A comprehensive study on the phenolic profile of widely used culinary herbs and spices: Rosemary, thyme, oregano, cinnamon, cumin and bay. Food Chemistry 154: 299-307. DOI: 10.1016/j.foodchem.2013.12.106.

Vernon R.S., Gillespie D.R. 1990. Spectral responsiveness of Frankliniella occidentalis (Thysanoptera: Thripidae) determined by trap catches in greenhouses. Environmental Entomology 19: 12291241. DOI: 10.1093/ee/19.5.1229.

Wijkamp I., Almarza N., Goldbach R., Peters D. 1995. Distinct levels of specificity in thrips transmission of tospoviruses. Phytopathology 85(10): 10691074. DOI: 10.1094/phyto-85-1069.

Wu S., Gao Y., Xu X., Wang E., Wang Y., Lei Z. 2014. Evaluation of Stratiolaelaos scimitus and Neoseiulus barkeri for biological control of thrips on greenhouse cucumbers. Biocontrol Science and Technology 24: 1110-1121. DOI: 10.1080/09583157.2014.924478.

Wu S., Gao Y., Smagghe G., Xu X., Lei Z. 2016. Interactions between the entomopathogenic fungus Beauveria bassiana and the predatory mite Neoseiulus barkeri and biological control of their shared prey/host Frankliniella occidentalis. Biological Control 98: 43-51. DOI: 10.1016/j.biocontrol.2016.04.001. 